\title{
THE EXTRARENAL CORRECTION OF ALKALOSIS ASSOCIATED WITH POTASSIUM DEFICIENCY ${ }^{1}$
}

\author{
By ROBERT E. COOKE, ${ }^{2}$ WILLIAM E. SEGAR, DONALD B. CHEEK, ${ }^{3}$ FRANCES E. \\ COVILLE, AND DANIEL C. DARROW
}

(From the Departments of Pediatrics and Physiology, Yale University School of Medicine, New Haven, Conn.)

(Submitted for publication April 21, 1952; accepted June 20, 1952)

The role of the kidney in the regulation of the $\mathrm{pH}$ of extracellular fluids has been adequately described $(1,2)$. However, although the alterations in muscle composition accompanying changes in acid-base balance have been pointed out (3), quantitative evaluation of the effects of these changes in muscle composition on the acid-base equilibrium of extracellular fluids has received little attention. The determination of the precise role of kidney and of muscle cell in modifying extracellular composition has been handicapped by the difficulty in designing experiments which separate the influence of different organs and systems. The need for a "body-less kidney" or a "kidney-less body" in the study of this problem has been emphasized by Darrow (4).

The physiological basis for metabolic alkalosis associated with potassium deficiency has not been satisfactorily determined. On the basis of changes in renal potassium excretion during administration of the carbonic anhydrase inhibitor, 6063, Berliner, Kennedy, and Orloff (5) have postulated that alkalosis in potassium deficiency results from the excessive substitution of hydrogen and ammonium ions for sodium in the distal tubule of the kidney. In this way chloride is excreted without sodium and hypochloremic alkalosis of the extracellular fluid results.

This paper presents the findings in experiments designed to test this hypothesis by simultaneous measurement of renal excretion and analysis of serum and muscle of rats during recovery from potassium deficiency alkalosis.

1 Aided by research grants from the United States Public Health Service and the James Hudson Brown Memorial Fund of the Yale University School of Medicine.

2 John and Mary R. Markle Scholar in Medical Science.

3 Medical Research Fellow, Rotary International Foundation.

\section{PLAN OF EXPERIMENTS AND METHODS}

Male albino rats, weighing 250-300 grams, were made alkalotic and potassium deficient in the course of $3 \frac{1}{2}$ weeks by the feeding of a potassium-deficient diet ${ }^{*}$ and the intraperitoneal injection of $2 \mathrm{mg}$. of desoxyccrticosterone acetate $(\mathrm{DCA})^{5}$ daily. An isotonic solution of sodium chloride and sodium acetate, with a molecular sodium to chloride ratio of $1.5 / 1.0$, was substituted for drinking water and was the sole source of sodium and chloride.

Animals were then divided into two groups of nine animals each and transferred to individual metabolism cages. Distilled water was substituted for the salt solution, DCA injections were discontinued but the diet was not modified. The intake of food by each group was grossly the same although paired feeding was not carried out. Even large differences in food intake could not significantly affect the urinary excretion since the diet was devoid of sodium, potassium, and chloride and contained only small quantities of phosphorus, calcium, magnesium, and trace elements. After three days a control urine collection for 24 hours was obtained.

Group $\mathrm{K}$ then received $3 \mathrm{mM}$ of $\mathrm{KCl}$ per kilogram of body weight twice daily, administered intraperitoneally as isotonic potassium chloride. Complete urine collections were obtained and analyzed each day. This dosage of potassium chloride approximates the maximum used in the repair of potassium deficiency in humans. Larger doses are poorly tolerated by the animals. Group $\mathrm{Na}$ received twice daily intraperitoneal injections of the equivalent amount of chloride as Group $\mathrm{K}$ in the form of isotonic sodium chloride and all urine was likewise collected and analyzed.

All cages, screens and funnels were treated with a silicone to facilitate rapid and complete drainage. All urine was collected under toluene and mineral oil. Feces were excluded from urine but were not analyzed. Other animals were treated similarly except that urine was not collected. These animals were sacrificed at the beginning of and at appropriate intervals throughout the

4 Constituents per $\mathrm{Kg}$. of Diet-dextrin 550 g., hydrogenated vegetable oil (Swiftning) 150 g., raw casein 100 g., vitaminized casein 100 g., corn oil 100 g., vitaminized corn oil 100 g., basic salts 5 g. (including calcium, phosphorus, iron, zinc, copper, manganese, magnesium).

5 Percorten, supplied by Ciba, Inc., Summit, N. J., whose generosity made possible these studies. 
experiment. Analyses of blood drawn from the abdominal aorta during ether anesthesia and of muscle after exsanguination were obtained on these animals as well as those studied in metabolism cages.

The methods of analysis are the same as were used earlier in this laboratory with the exception that sodium and potassium were determined by a Barclay internal standard flame photometer. The microdiffusion method of Conway (6) was used for analysis of ammonia in urine. The Beckman $\mathrm{pH}$ meter was used for the determination of $\mathrm{pH}$ and titratable acidity by titration with $\mathrm{N} / 100 \mathrm{NaOH}$ to $\mathrm{pH} 7.40$. It should be pointed out that serum $\mathrm{pH}$ is subject to the largest temporary variations of the quantities measured because of alterations in respiratory activity associated with anesthesia and exsanguination. The carbon dioxide content and chloride concentrations are therefore more significant indicators in rats of disturbance of acid-base balance.

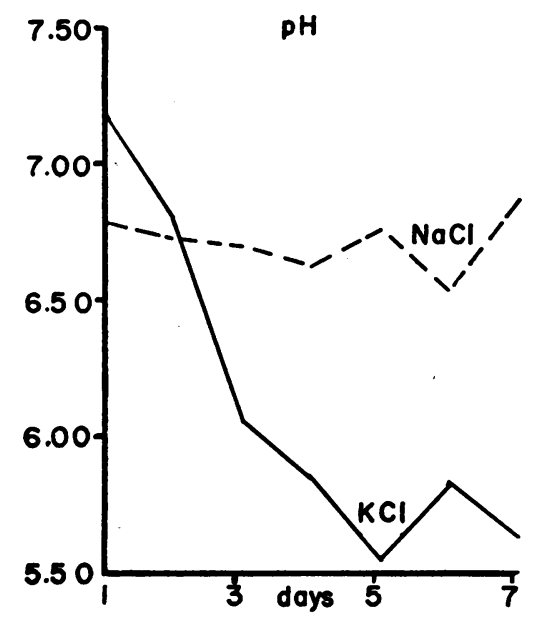

Fig. 1. Average Urine pH in Groups K and Na

\section{RESULTS}

Results are presented as the mean of each group since the variations among animals of the same group were small. The significant trends in urinary excretion which occurred during the course of the experiments were observed in every animal studied.

There was essentially no difference in mean renal excretion between Groups $\mathrm{K}$ and $\mathrm{Na}$ during the control period (day 1 in Figures $1-8$ ). There was a marked difference in composition of urine between Groups $\mathrm{K}$ and $\mathrm{Na}$ after injections of potassium and sodium chloride were begun.

Group $\mathrm{K}$ excreted urine of lower $\mathrm{pH}$ and bicarbonate content and higher titratable acidity than Group Na. These findings became more marked as the experiment progressed (Figures 1, 2, 3).

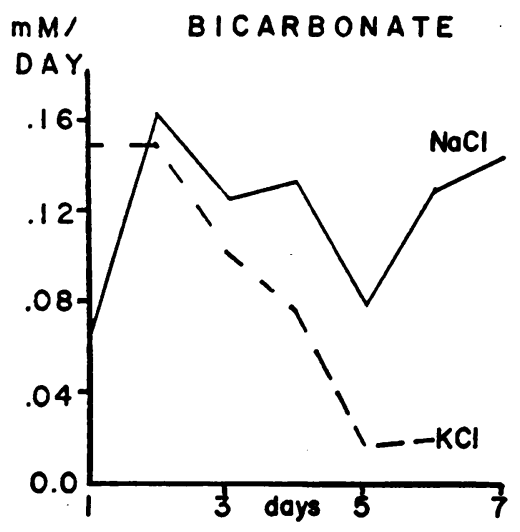

Fig. 2. Average Bicarbonate Excretion in Groups $\mathrm{K}$ AND Na

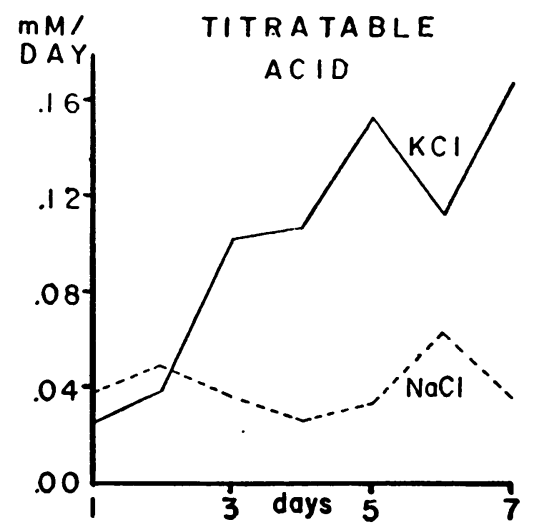

Fig. 3. Average Titratable Acid Excretion in Groups $\mathrm{K}$ AND NA

The ammonia excretion was somewhat greater in Group $\mathrm{K}$ than in Group $\mathrm{Na}$ (Figure 4). In Group $\mathrm{K}$ there was marked increase in the excre-

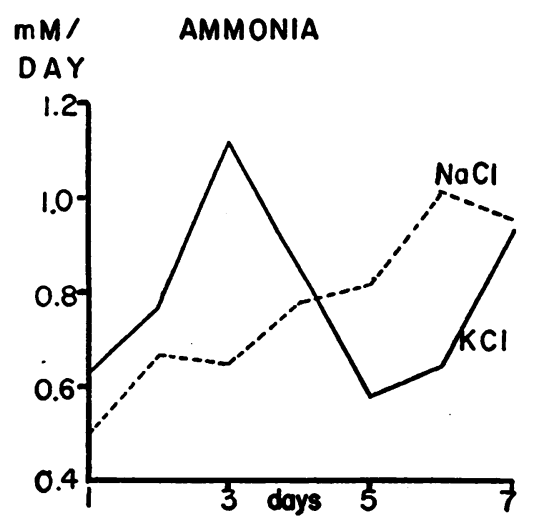

Fig. 4. Average Ammonia Excretion in Groups $\mathbf{K}$ AND NA 
tion of sodium after the injection of $6 \mathrm{mM}$ of potassium per kilogram of body weight, although no sodium had been taken for five days (Figure 5). This loss of sodium diminished after $18-24 \mathrm{mM} /$

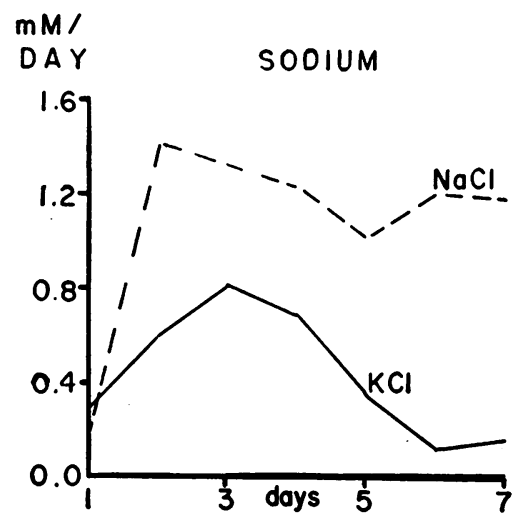

Fig. 5. Average Sodium Excretion in Groups $\mathrm{K}$ AND NA

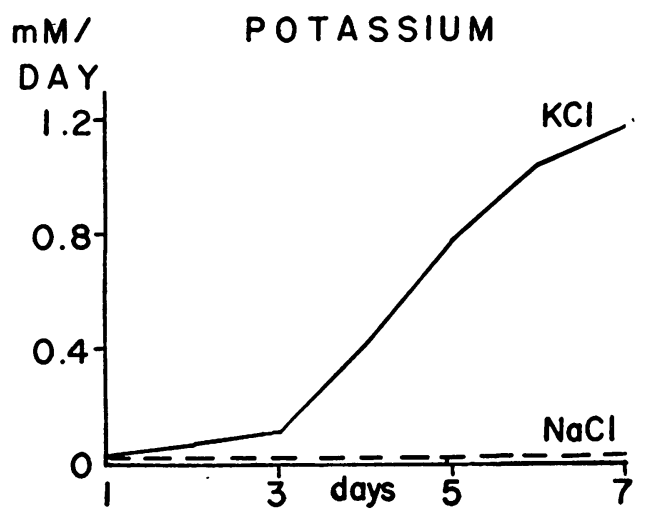

Fig. 6. Average Potassium Excretion in Groups K AND NA

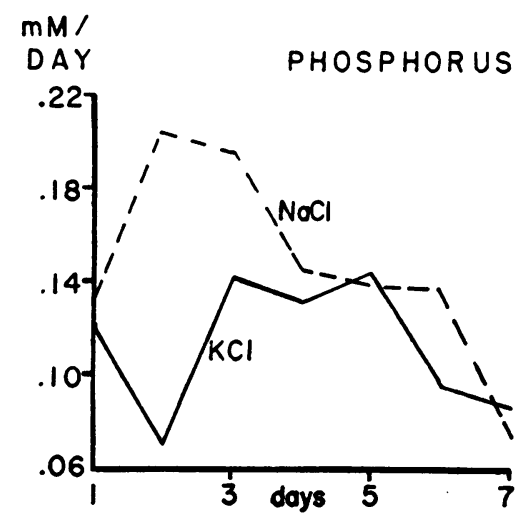

Fig. 7. Average Phosphorus Excretion in Groups $\mathrm{K}$ AND NA
$\mathrm{Kg}$. of potassium had been administered. In those animals receiving sodium chloride the excretion of sodium was almost equivalent to the administered sodium from the first day of the experiment (Figure 5).

The excretion of potassium by Group $\mathrm{K}$ did not increase significantly until $12 \mathrm{mM} / \mathrm{Kg}$. of potassium had been injected (Figure 6) and it was not until $24 \mathrm{mM} / \mathrm{Kg}$. had been administered that excretion of potassium approximated the intake. There was essentially no increase in potassium excretion in those animals given sodium chloride (Figure 6).

There was a fall in phosphorous excretion after the administration of $6 \mathrm{mM} / \mathrm{Kg}$. of potassium but there was no consistent difference in the excretion of phosphorus between the two groups of animals (Figure 7). There was no uniform difference in $\mathrm{Cl}$ excretion between the two groups (Figure 8).

The average cumulative balance of potassium, sodium and chloride was calculated for each group of animals. The intake of each ion was that administered by injection. The loss of these ions in the feces was not included in the calculation of outgo and probably produces a small but significant error in the potassium balance only. In the potassium chloride treated animals the retention of potassium amounted to $20.2 \mathrm{mM} / \mathrm{Kg}$. of body weight over six days and the loss of sodium amounted to $10.8 \mathrm{mM} / \mathrm{Kg}$. of body weight. The retention of chloride was less than the sum of the retentions of sodium and potassium. This difference was more marked in the animals receiving potassium chloride than in those receiving sodium chloride (Figure 9).

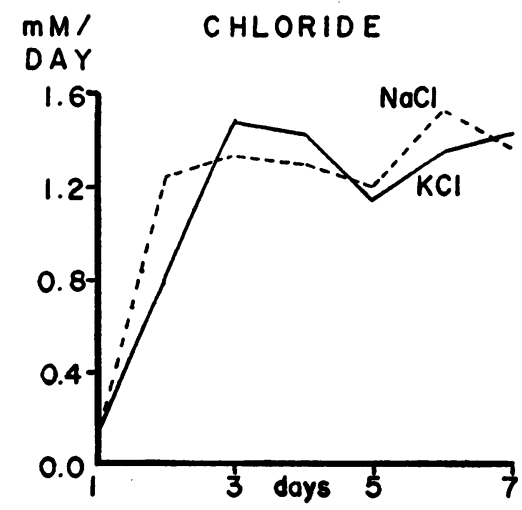

Fig. 8. Average Chloride Excretion in Groups $\mathrm{K}$ AND NA 


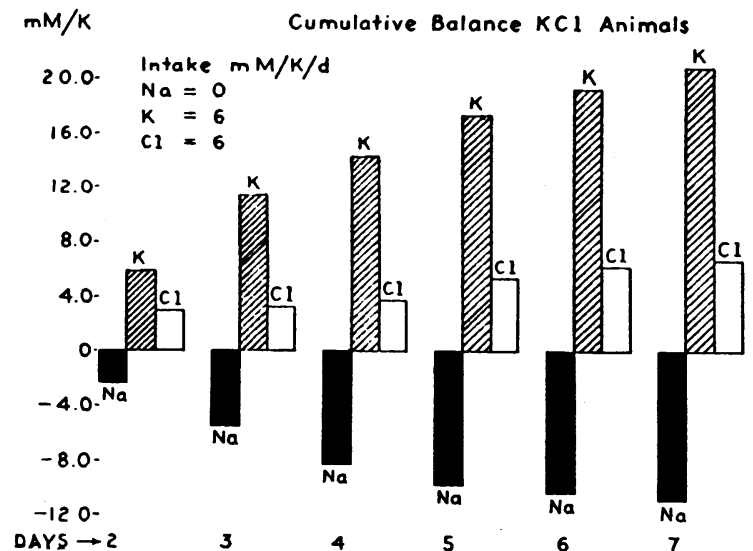

Fig. 9. Cumulative Balance of Sodium, Potassium, and Chloride in Potassium (_hloride Treated Animals

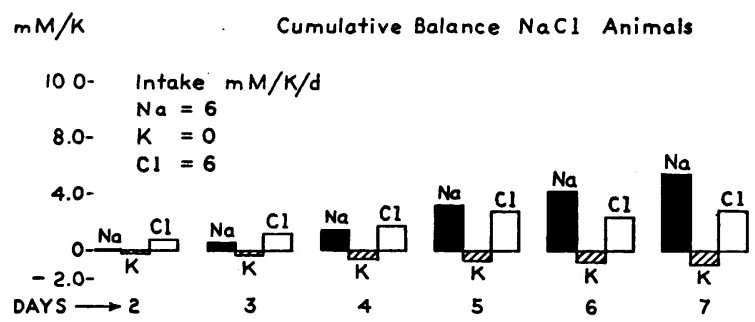

Fig. 10. Cumulative Balance of Sodium, Potassium, and Chloride in Sodium Chloride Treated Animals

There were insignificant retentions of sodium and chloride and a very small loss of potassium in the animals that received sodium chloride (Figure 10).

Analysis of serum during and at the end of the experiment revealed complete correction of the extracellular hypochloremic alkalosis in those animals receiving potassium chloride (initial serum bicarbonate concentration $=30.0 \mathrm{mM} / \mathrm{L}$, final se-
TABLE II

Average muscle composition per $100 \mathrm{~g}$. fat-free solids

\begin{tabular}{|c|c|c|c|c|c|c|c|}
\hline Group & No. & $\mathrm{H}_{2} \mathrm{O}$ & $\mathrm{Cl}$ & $\mathrm{Na}$ & $\mathbf{K}$ & Phos. & $\mathrm{Na}$ \\
\hline 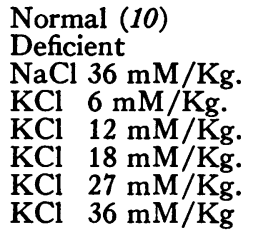 & $\begin{array}{l}8 \\
8 \\
7 \\
6 \\
7 \\
4 \\
2\end{array}$ & $\begin{array}{l}340 \\
332 \\
332 \\
330 \\
327 \\
320 \\
322 \\
317\end{array}$ & \begin{tabular}{l|}
7.1 \\
5.5 \\
4.81 \\
5.8 \\
5.7 \\
5.7 \\
5.97 \\
4.89
\end{tabular} & $\begin{array}{l}10.0 \\
18.4 \\
18.1 \\
17.5 \\
13.7 \\
12.1 \\
10.7 \\
10.1\end{array}$ & $\begin{array}{l}48.9 \\
34.2 \\
33.0 \\
36.7 \\
40.9 \\
43.6 \\
42.0 \\
45.7\end{array}$ & $\begin{array}{l}32.4 \\
34.3 \\
35.5 \\
35.2 \\
35.0 \\
34.5 \\
35.9\end{array}$ & $\begin{array}{r}2.4 \\
12.2 \\
13.0 \\
11.2 \\
7.8 \\
6.3 \\
4.3 \\
5.3\end{array}$ \\
\hline
\end{tabular}

rum bicarbonate concentration $=23.1 \mathrm{mM} / \mathrm{L}$ ). By contrast those animals receiving sodium chloride showed the same bicarbonate concentrations at the end as at the beginning of the experiment (Table I).

Analysis of muscle in both groups at the beginning of the experiment revealed the characteristic changes in composition noted previously in potas-

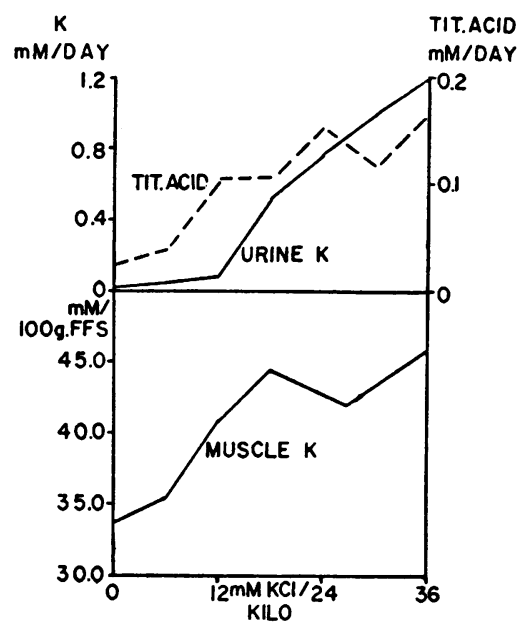

Fig. 11. Relationship of Urine Potassium and Titratable Acidity to Change in Muscle Potassium During Administration of Potassium Chloride

TABLE I

Average serum analyses

\begin{tabular}{|c|c|c|c|c|c|c|c|c|c|c|c|}
\hline Group & No. & $\mathrm{pH}$ & $\mathrm{H}_{2} \mathrm{O}$ & $\mathrm{Na}$ & $\mathbf{K}$ & $\mathrm{Cl}$ & $\mathrm{HCO}_{2}$ & {$[\mathrm{Na}]$} & {$[\mathbf{K}]$} & {$[\mathrm{Cl}]$} & [HCOs] \\
\hline & & & g./L & $m M / L$ & $m M / L$ & $m M / L$ & $m M / L$ & \multicolumn{4}{|c|}{$m M / K g$. of water in ultrafiltrate of serum* } \\
\hline $\begin{array}{l}\text { Normal (10) } \\
\text { Deficient } \\
\mathrm{NaCl} 36 \mathrm{mM} / \mathrm{Kg} . \\
\mathrm{KCl}\end{array}$ & $\begin{array}{l}8 \\
8 \\
7 \\
6 \\
7 \\
4 \\
2\end{array}$ & $\begin{array}{l}7.28 \\
7.46 \\
7.46 \\
7.50 \\
7.39 \\
7.39 \\
7.43 \\
7.45\end{array}$ & $\begin{array}{l}935 \\
935 \\
935 \\
935 \\
935 \\
935 \\
935 \\
935\end{array}$ & $\begin{array}{l}143 \\
143 \\
143 \\
141 \\
141 \\
141 \\
141 \\
141\end{array}$ & $\begin{array}{l}5.4 \\
2.7 \\
2.9 \\
3.3 \\
4.3 \\
4.7 \\
4.4 \\
4.6\end{array}$ & $\begin{array}{r}103 \\
93 \\
96 \\
96 \\
103 \\
104 \\
101 \\
105\end{array}$ & $\begin{array}{l}21 \\
30 \\
30 \\
26 \\
23 \\
23 \\
24 \\
23\end{array}$ & $\begin{array}{l}145 \\
145 \\
145 \\
144 \\
144 \\
144 \\
143 \\
143\end{array}$ & $\begin{array}{l}5.4 \\
2.7 \\
2.9 \\
3.3 \\
4.3 \\
4.7 \\
4.4 \\
4.6\end{array}$ & $\begin{array}{l}115 \\
105 \\
108 \\
109 \\
116 \\
117 \\
114 \\
118\end{array}$ & $\begin{array}{l}23 \\
33 \\
34 \\
29 \\
26 \\
26 \\
27 \\
25\end{array}$ \\
\hline
\end{tabular}

* Donnan factor $=0.95$. 


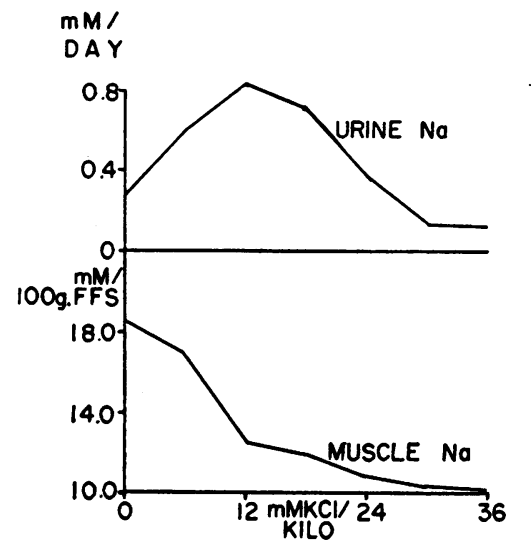

Fig. 12. Relationship of Urine Sodium to Change in Muscle Sodium During Administration of PotasSIUM CHLORIDE

sium deficiency (3). There was marked increase in muscle sodium and decrease in muscle potassium (Table II). The increase in intracellular sodium amounted to about two-thirds of the decrease in intracellular potassium as described earlier $(3,7) . \quad\left(\Delta \mathrm{Na}_{1}=-2 / 3 \Delta \mathrm{K}_{1}\right)$. In group $K$, analysis of muscle during and at the end of the experiment revealed a gradual return toward normal composition (Table II). The fall in intracellular sodium during repair lagged somewhat behind the rise in intracellular potassium. The changes in muscle composition were reflected in equivalent changes in urinary excretion (Figures 11 and 12).

\section{DISCUSSION}

The results of these experiments present a paradox. Thus, although renal regulation must ultimately determine extracellular composition, the rats receiving potassium chloride recovered from metabolic alkalosis while the kidneys excreted a urine with greater titratable acidity and ammonia and lower bicarbonate content than the rats receiving sodium chloride. Furthermore, the rats receiving potassium chloride excreted chloride in excess of sodium plus potassium. If these excretions are considered from the point of view of extracellular fluid alone, recovery from alkalosis is not explained. The urine findings and the correction of extracellular alkalosis must then be the result of exchange of ions between extracellular fluid and muscle cell. In effect these potassiumdeficient, alkalotic rats from the standpoint of the body as a whole had a deficit of fixed cation which was in excess of the deficit of fixed anion. Thus the chloride excretion during repair was greater than the sum of the sodium and potassium excretions. Likewise the deficit of potassium in the body was considerably greater than the excess of sodium.

The magnitude of these disturbances and the nature of the exchange of ions between cell and extracellular fluid are indicated by muscle analysis. Darrow and his associates (3), originally, and Muntwyler and Griffin (7), subsequently, demonstrated that, in potassium deficiency with alkalosis, the rise in intracellular sodium amounted to approximately two-thirds of the fall in intracellular potassium. Since normal muscle composition is restored by the administration of potassium chloride, approximately three potassium ions must have entered the cell for every two sodium ions leaving it during repair (Figure 13). If electrical neutrality is to be maintained, some cation other than sodium must have been exchanged for potassium. The data of Cotlove and his associates (8) indicate that the other cation exchanged is not calcium or magnesium. By exclusion the exchange of hydrogen ion from within the cell for potassium of extracellular fluid must have occurred. This exchange of hydrogen ion for fixed cation is identical with the concept of change in base-binding capacity of the cell anion, since the basis of alteration in base-binding capacity of anion is the substitution of hydrogen ion for fixed cation with alteration in dissociation of the compound that results.

$$
\mathrm{H}^{+}+\mathrm{K}^{+}+\mathrm{A}^{-} \rightleftarrows \mathrm{HA}+\mathrm{K}^{+}
$$

The exchange of extracellular potassium for intracellular hydrogen lowers the extracellular bicarbonate concentration if potassium is administered along with a fixed anion such as chloride. By this exchange a strong acid is formed which reacts with extracellular bicarbonate to form carbon dioxide.

$$
\begin{aligned}
& \mathrm{H}^{+} \\
& \text {(from cell in exchange for } \mathrm{K}^{+} \text {) } \\
& \mathrm{CO}_{2}+\mathrm{H}_{2} \mathrm{O} \\
& +\mathrm{Cl}^{-}+\mathrm{Na}^{+}+\mathrm{HCO}_{3}^{-} \rightleftarrows \mathrm{Na}^{+}+\mathrm{Cl}^{-}+\stackrel{\mathrm{H}_{2}}{\mathrm{CO}_{3}}
\end{aligned}
$$


It is likely that the interchange of hydrogen for potassium which is described is not a reaction which is suddenly initiated under these particular circumstances but rather is an established equilibrium, such as may occur in yeast (9). The net exchange described would result from an alteration in the equilibrium point with an altered concentration of reactants on each side of the membrane.

During repair of alkalosis with potassium chloride the magnitude of the change in extracellular composition which is imposed by the transfer of electrolyte from the cell can be readily calculated from the changes in intracellular composition. The net exchange of sodium, potassium, chloride and hydrogen ions at the membrane will be reflected in changes in extracellular composition and in altered excretion of anions and cations by the kidney.

In the calculation of the theoretical balance of electrolyte from changes in muscle composition three quite probable assumptions are made. First, muscle is assumed to make up 50 per cent of the body weight. Second, extracellular fluid is assumed to be 20 per cent of the body weight after correction with potassium chloride. Third, the fatfree solids (FFS) of muscle are considered to remain constant over a short period of time. The actual body balance of chloride, sodium and potassium after $18 \mathrm{mM}$ per kilogram of potassium chloride had been injected (three days) is of the same order of magnitude as the theoretical balance calculated from observed changes in muscle composition during the same period of study. The balances are compared for this period of study rather than at the end of one week to minimize cumulative errors arising from undetermined losses and to emphasize the large changes in body composition which occur rapidly. It is assumed that the determined balance of chloride, $3.7 \mathrm{mM} / \mathrm{Kg}$., remains in extracellular fluid. This balance of extracellular chloride is used to calculate the change in extracellular volume according to the method of Darrow (10).

$$
\begin{aligned}
& \text { Calculations: }{ }^{6} \text { per kilogram of body weight } \\
& \qquad \begin{aligned}
(\mathrm{Cl})_{2} & =\left(\mathrm{H}_{2} \mathrm{O}\right)_{\mathrm{e}_{2}} \times[\mathrm{Cl}]_{2} \\
& =.200 \times 117=23.4 \mathrm{mM}
\end{aligned}
\end{aligned}
$$

( ( ) refers to the total amount in $\mathrm{mM}$ or $\mathrm{Kg}$. [ ] refers to concentration in ultrafiltrate of serum in $\mathrm{mM}$ per kilo-

$$
\begin{aligned}
(\mathrm{Cl})_{1} & =(\mathrm{Cl})_{2}-\Delta(\mathrm{Cl}) \\
& =23.4-3.7=19.7 \mathrm{mM} \\
\left(\mathrm{H}_{2} \mathrm{O}\right)_{\mathrm{e} 1} & =\frac{(\mathrm{Cl})_{1}}{[\mathrm{Cl}]_{1}} \\
& =\frac{19.7}{105}=0.188 \mathrm{Kg} . \\
(\mathrm{Na})_{2} & =\left(\mathrm{H}_{2} \mathrm{O}\right)_{\mathrm{e}_{2}} \times[\mathrm{Na}]_{2}+\mathrm{FFS} \times(\mathrm{Na})_{\mathrm{i}_{2}} / 100 \mathrm{~g} . \mathrm{FFS} \\
& =.200 \times 144+\frac{120}{100} \times 6.3 \\
& =36.4 \mathrm{mM} \\
(\mathrm{Na})_{1} & =\left(\mathrm{H}_{2} \mathrm{O}_{\mathrm{e}}\right)_{1} \times[\mathrm{Na}]_{1}+\mathrm{FFS} \times \mathbf{l}(\mathrm{Na})_{\mathrm{i}_{1}} / 100 \mathrm{~g} . \mathrm{FFS} \\
& =.188 \times 145+\frac{120}{100} \times 12.2 \\
& =41.9 \mathrm{mM} \\
\Delta(\mathrm{Na}) & =(\mathrm{Na})_{2}-(\mathrm{Na})_{1}=-5.5 \mathrm{mM}
\end{aligned}
$$

Likewise $\quad$

$$
\Delta(\mathrm{K})=(\mathrm{K})_{2}-(\mathrm{K})_{1}=+11.6 \mathrm{mM}
$$

The theoretical balance of chloride is by assumption equal to the actual balance $=+3.7 \mathrm{mM} / \mathrm{Kg}$.

Theoretical $\mathrm{Na}$ Balance $=-5.5 \mathrm{mM} / \mathrm{Kg}$. Actual $\mathrm{Na}$ Balance $=-8.2 \mathrm{mM} / \mathrm{Kg}$.

Theoretical $\mathrm{K}$ Balance $=+11.6 \mathrm{mM} / \mathrm{Kg}$. Actual $\mathrm{K}$ Balance $=+14.3 \mathrm{mM} / \mathrm{Kg}$.

If the difference between the decrease in sodium within muscle $\left(\Delta(\mathrm{Na})_{1}\right)$ and the increase in potassium $\left(\Delta(\mathrm{K})_{1}\right)$ during repair with potassium chloride is assumed to be mainly hydrogen ion transferred from cells to extracellular fluid, it is possible to calculate the theoretical decrease in the amount of extracellular bicarbonate (theoretical $\left.\Delta\left(\mathrm{HCO}_{3}\right)_{\mathrm{e}}\right)$ which results from extrarenal correction. The nomogram of Singer and Hastings (11) is also used to correct for the buffering capacity of whole blood with the observed change in $\mathrm{pH}$.

$$
\begin{aligned}
& \text { Calculation: per kilogram of body weight } \\
& \left(\mathrm{HCO}_{3}\right)_{\mathrm{e}_{2}}=\left(\mathrm{H}_{2} \mathrm{O}\right)_{\mathrm{eq}} \times\left[\mathrm{HCO}_{3}\right]_{\mathrm{eq}} \\
& =.200 \times 26=5.2 \mathrm{mM} \\
& \left(\mathrm{HCO}_{8}\right)_{\mathrm{e}_{1}}=\left(\mathrm{H}_{2} \mathrm{O}\right)_{\mathrm{e}_{1}} \times\left[\mathrm{HCO}_{3}\right]_{\mathrm{e}_{1}} \\
& =.188 \times 33=6.2 \mathrm{mM} \\
& \Delta\left(\mathrm{HCO}_{3}\right)_{\mathrm{e}}=\left(\mathrm{HCO}_{3}\right)_{\mathrm{e} 2}-\left(\mathrm{HCO}_{3}\right)_{\mathrm{e}}=-1.0 \mathrm{mM} \\
& \Delta \text { Buffer base (Calculated) } \quad=-0.3 \mathrm{mM} \\
& \text { Actual } \Delta\left(\mathrm{HCO}_{z}\right)_{\mathrm{a}} \quad=-1.3 \mathrm{mM} / \mathrm{Kg} \text {. }
\end{aligned}
$$

Calculation of theoretical $\Delta\left(\mathrm{HCO}_{3}\right)_{\mathrm{e}}$ from $\mathrm{H}$ transport

$$
\begin{aligned}
(\mathrm{Na})_{\mathrm{i}_{2}} & =\text { FFS } \quad \times(\mathrm{Na})_{\mathrm{i}_{2}} / 100 \mathrm{~g} . \mathrm{FFS} \\
& =\frac{120}{100} \quad \times 6.3=7.6 \mathrm{mM}
\end{aligned}
$$

gram of water. $\left(\mathrm{H}_{2} \mathrm{O}\right)$ refers to volume of fluid in kilograms. FFS refers to fat-free solids of muscle in grams and equaled $120 \mathrm{~g} . / \mathrm{Kg}$. of rat. Subscripts "e" and "i" refer to extracellular and intracellular, respectively. Subscripts " 1 " and " 2 " refer to values before and after correction, respectively. 


$$
\begin{aligned}
(\mathrm{Na})_{\mathrm{i}_{1}} & =\mathrm{FFS} \quad \times(\mathrm{Na})_{\mathrm{i}_{1}} / 100 \mathrm{~g} . \mathrm{FFS} \\
& =\frac{120}{100} \quad \times 12.2=14.6 \mathrm{mM} \\
\Delta(\mathrm{Na})_{\mathrm{i}_{1}} & =(\mathrm{Na})_{\mathrm{i}_{2}}-(\mathrm{Na})_{\mathrm{i}_{1}}=-7.0 \mathrm{mM}
\end{aligned}
$$

Likewise

$$
\Delta(\mathrm{K})_{\mathrm{i}}=(\mathrm{K})_{\mathrm{i}_{2}}-(\mathrm{K})_{\mathrm{i}_{1}}=11.2 \mathrm{mM}
$$

Theoretical $\Delta\left(\mathrm{HCO}_{3}\right)_{e}=-\Delta(\mathrm{Na})_{\mathrm{i}}-\Delta(\mathrm{K})_{\mathrm{i}}$

$$
=-4.2 \mathrm{mM} / \mathrm{Kg} \text {. }
$$

Theoretical $\Delta\left(\mathrm{HCO}_{8}\right)_{\mathrm{e}}=-4.2 \mathrm{mM} / \mathrm{Kg}$. Actual

$$
\Delta\left(\mathrm{HCO}_{3}\right)_{\mathrm{e}}=-1.3 \mathrm{mM} / \mathrm{Kg} \text {. }
$$

As can be seen from the above calculations, the fall in extracellular bicarbonate calculated from change in muscle composition is considerably greater than that actually measured and is equivalent to most of the bicarbonate normally present in extracellular fluid. The reason for the discrepancy is obvious in view of the urinary findings during repair with potassium chloride. The presence of low urine $\mathrm{pH}$, high titratable acid and ammonia excretion, as well as low bicarbonate output, indicates some renal compensation to prevent extracellular acidosis which results from transfer of large quantities of hydrogen from the cells. The hydro-

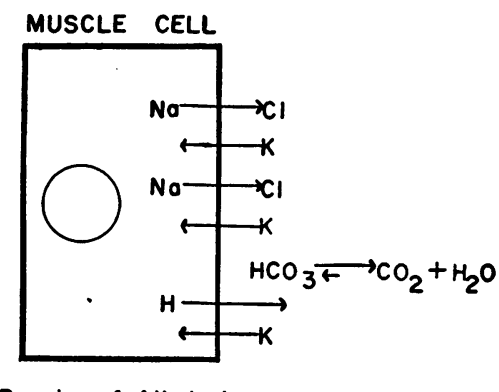

Repair of Alkolosis

Fig. 13. Cell Transfer Correcting Alkalosis with administration of Potassium Chloride

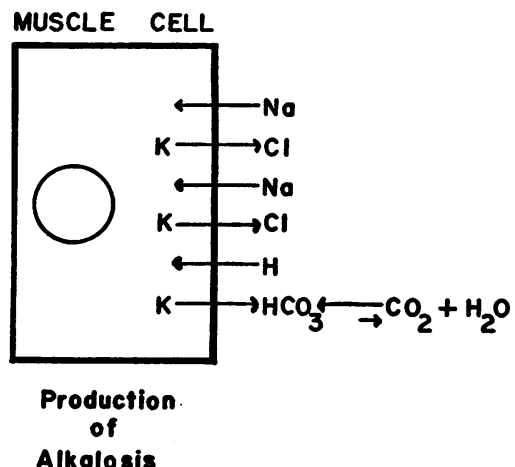

Fig. 14. Cell Transfer Producing Alkalosis in PoTASSIUM LOSS gen ion excreted as titratable acid and the difference in ammonia excretion between the two groups of animals may be considered equivalent to potential extracellular bicarbonate (a probably valid assumption since it represents fixed cation reabsorbed without fixed anion). The actual change in extracellular bicarbonate plus the bicarbonate conserved by the kidney (the sum $=$ Effective $\left.\Delta\left(\mathrm{HCO}_{3}\right)_{e}\right)$ is of the same order of magnitude as the potential theoretical fall in extracellular bicarbonate as derived from muscle analysis.

$$
\begin{aligned}
\text { Actual } & \Delta\left(\mathrm{HCO}_{3}\right)_{\mathrm{e}} & =-1.3 \\
+ & \text { Tit. Ac. } & =-1.0 \\
+ & \mathrm{NH}_{\mathrm{z}} & =-2.5 \\
+ & \Delta\left(\mathrm{HCO}_{3}\right)_{e} & =-4.8 \mathrm{mM} / \mathrm{Kg} . \\
\text { Effective } & \text { Theoretical }^{\Delta}\left(\mathrm{HCO}_{3}\right)_{\mathrm{e}} & =-4.2 \mathrm{mM} / \mathrm{Kg} .
\end{aligned}
$$

The data presented illustrate the correction of extracellular alkalosis associated with potassium deficiency by the transfer of electrolyte between muscle cells and the surrounding fluids. The converse reactions between muscle cells and extracellular fluid must occur during the development of this type of change in body composition, i.e., in alkalosis associated with potassium deficiency. Figure 14 is a schematic representation of the transfers of electrolyte during development of potassium deficiency. It is, of course, obvious that dissolved carbon dioxide (carbonic acid) produced by the cells does not represent a load to be excreted by the kidney and that with intact respiratory mechanisms carbon dioxide is of little importance in altering the electrolyte pattern of extracellular fluids. The exchange of fixed cation from the cell for hydrogen ion, which is derived from the dissociation of carbonic acid of extracellular fluid, produces the same effect on extracellular composition as would the addition of potassium bicarbonate to the extracellular space. Under these conditions extracellular bicarbonate concentration must rise unless the kidneys excrete fixed cation in excess of fixed anion.

It is clear from the calculations of the theoretical bicarbonate reduction which is produced by exchange at the cell membrane during recovery. from potassium deficiency that a corresponding production of bicarbonate occurs during genesis of potassium deficiency. It is not clear, however, why the kidneys in potassium deficiency do not compensate for this load of fixed cation in excess 
of fixed anion and thereby preserve extracellular electrolyte concentration. A satisfactory explanation of this failure in renal regulation of extracellular composition would probably also explain the failure of sodium chloride to correct the extracellular alkalosis associated with potassium deficiency.

If the changes in composition that have been described for muscle in alkalosis associated with potassium deficiency also apply to the cells of the distal tubule of the kidney, these abnormalities in renal adjustment of alkalosis could be explained. These cells would then contain an excess of sodium and hydrogen ions and a deficiency of potassium. Excretion of sodium in excess of chloride would thus be impaired as postulated by Berliner, Kennedy, and Orloff (5). Analysis of rats with potassium deficiency did not reveal such a change in the composition of whole kidneys (12). If such a change occurs in certain cells, it is obscured by the method of analysis which, of necessity, included all cells, tubular urine, and extracellular fluid.

\section{SUMMARY}

Alkalosis associated with potassium deficiency was produced in rats by injection of desoxycorticosterone acetate while on a diet deficient in potassium and containing an excess of sodium over chloride. Over a period of six days one group of these animals received injections of $6 \mathrm{mM} / \mathrm{Kg}$. of potassium chloride daily, while another group received $6 \mathrm{mM} / \mathrm{Kg}$. of sodium chloride per day.

The group receiving potassium chloride restored serum and muscle composition to normal over a period of three to six days. This repair was accompanied by an increase in urinary titratable acidity and ammonia. The sodium chloride group showed no correction of serum or muscle composition and there was no change in urinary titratable acidity and ammonia over this period.

It is pointed out that the repair of alkalosis in the rats receiving potassium chloride is accounted for by the transport of electrolyte between muscle and extracellular fluids. Since the gain of potassium by the cells is greater than the loss of sodium from the cells, hydrogen ion must be exchanged to preserve electrical neutrality. The calculated net exchange of hydrogen ion from cell to extracellular fluid is sufficient to account for the reduction in serum bicarbonate concentration and the increase in urinary titratable acidity and ammonia.

A general theory of extrarenal modification of acid-base balance is formulated from these findings.

\section{REFERENCES}

1. Gamble, J. L., Chemical Anatomy, Physiology and Pathology of Extracellular Fluid. Harvard University Press, Cambridge, Mass., 1947.

2. Pitts, R. F., and Lotspeich, W. D., Bicarbonate and the renal regulation of acid base balance. Am. J. Physiol., 1946, 147, 138.

3. Darrow, D. C., Schwartz, R., Iannucci, J. F., and Coville, F., Relation of serum bicarbonate concentration to muscle composition. J. Clin. Invest., 1948, 27, 198.

4. Darrow, D. C., Renal function. Transactions of the Third Conference of The Josiah Macy, Jr. Foundation, 1951, in press.

5. Berliner, R. W., Kennedy, T. J., Jr., and Orloff, J., Relationship between acidification of the urine and potassium metabolism; effect of carbonic anhydrase inhibition on potassium excretion. Am. J. Med., 1951, 11, 274.

6. Conway, E. J., Microdiffusion Analysis and Volumetric Error. Lockwood \& Son, Ltd., London, 1950, 3rd ed.

7. Muntwyler, E., and Griffin, G. E., Effect of potassium on electrolytes of rat plasma and muscle. J. Biol. Chem., 1951, 193, 563.

8. Cotlove, E., Holliday, M. A., Schwartz, R., and Wallace, W. M., Effects of electrolyte depletion and acid-base disturbance on muscle cations. Am. J. Physiol., 1951, 167, 665.

9. Conway, E. J., Biological interlinkage of acid-alkali formation with ion transport and synthetic reduction. Irish J. M. Sc., 1949, No. 288, 787.

10. Darrow, D. C., Retention of electrolyte during recovery from severe dehydration due to diarrhea. J. Pediat., 1946, 28, 515.

11. Singer, R. B., and Hastings, A. B., An improved clinical method for the estimation of disturbances of the acid-base balance of human blood. Medicine, 1948, 27, 223.

12. Darrow, D. C., and Cooke, R. E., Kidney composition in potassium deficiency. To be published. 